\title{
Rare cause of voiding dysfunction in an adult man: urethral diverticulum compressing the anterior urethra
}

Siddharth Pandey, Ajay Aggarwal, Deepanshu Sharma, Apul Goel

Department of Urology, King George's Medical University, Lucknow, Uttar Pradesh, India

\section{Correspondence to Dr Siddharth Pandey, sid1420@gmail.com}

Accepted 29 June 2018

\section{DESCRIPTION}

A 46-year-old man presented to us with lower urinary tract symptoms that include severe voiding symptoms. He had a history of injury to the perineum 3 years back. A smooth cystic swelling was palpable in the perineum in midline. Uroflowmetry was done and was suggestive of poor urinary flow $\left(\mathrm{Q}_{\mathrm{ayg}}: 2 \mathrm{~mL} / \mathrm{s}\right.$ and $\left.\mathrm{Q}_{\max }: 6 \mathrm{~mL} / \mathrm{s}\right)$, with significant postvoid residual urine (PVR). A micturating cystourethrogram (MCU) with retrograde urethrography (RUG) was done and was suggestive of an anterior urethral diverticulum, which was compressing the urethra, along with significant PVR (figure 1). The patient was planned for open excision of the urethral diverticulum. A cystourethroscopy was done preoperatively and clearly showed a normal anterior urethra and the opening of the diverticulum on the ventral aspect of the urethra (figure 2). The patient was operated in lithotomy position and a midline perineal incision was done. The diverticulum was dissected free and then excised, and the urethra was primarily closed over a $16 \mathrm{~F}$ Foley catheter (figure 3). The catheter was removed after 2 weeks, after which the patient voided well. Six months postoperatively, the patient is doing fine.

Anterior urethral diverticulum is a rare entity with description in the literature limited to case reports and a few small case series. Approximately

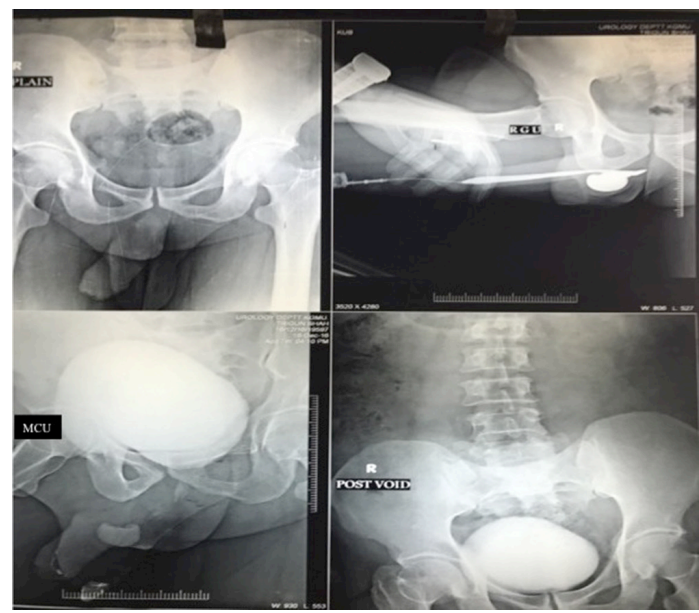

Figure 1 Micturating cystourethrogram (MCU) and retrograde urethrography (RUG) of the patient demonstrating the anterior urethral diverticulum in the RUG and significant postvoid residual urine.

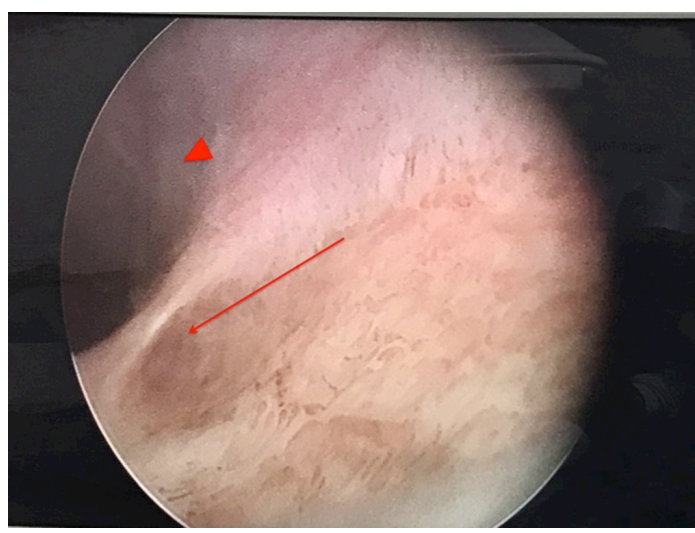

Figure 2 Cystourethroscopic view showing the opening of the diverticulum (arrow) and the normal urethra (arrowhead).

two-thirds of cases of anterior urethral diverticulum are acquired, while the remaining one-third are congenital. Acquired urethral diverticulum can be secondary to trauma, stricture or previous surgery. Patients with urethral diverticulum may be asymptomatic or have voiding symptoms such as poor urinary stream, postvoid dribbling and urinary tract infection. ${ }^{1}$ It may be palpable clinically and may be compressible. A RUG with MCU may aid in the diagnosis of a urethral diverticulum. As in a female urethral diverticulum, MRI is not always required. Cystourethroscopy is a valuable tool in such cases as the opening of the diverticulum can be visualised easily. ${ }^{2} \mathrm{~A}$ small asymptomatic urethral diverticulum can be managed non-operatively by advising the patient

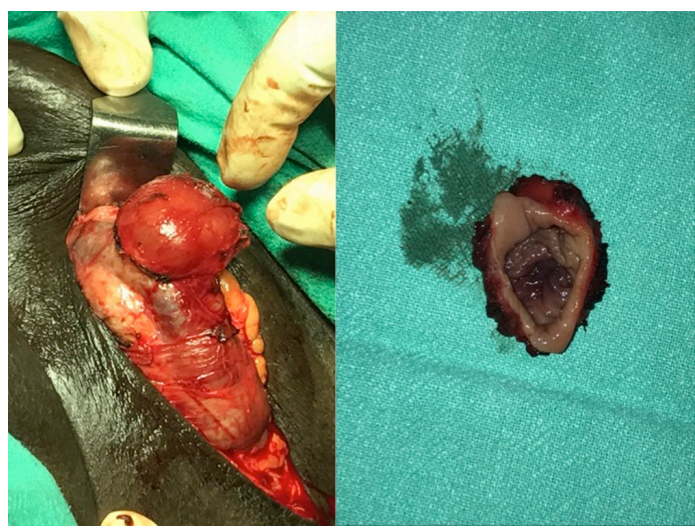

Figure 3 Intraoperative image of the diverticulum (left) and the excised diverticulum (right). 
to manually compress the diverticulum after voiding (so that there is no urinary stasis). Surgical options for management include endoscopic and open approaches. The endoscopic approach has a high chance of recurrence so an open approach is usually preferred. A small defect after excision

\section{Learning points}

- Anterior urethral diverticulum in men is a rare condition, and its symptoms mimic other common conditions such as urethral stricture.

- It may be clinically palpable, and retrograde urethrography and micturating cystourethrogram are useful in the investigation and diagnosis; cystourethroscopy is a valuable adjunct.

- The best management for symptomatic urethral diverticulum is open excision, followed by primary closure of the urethra for short defects or placement of a graft for larger defects. of the diverticulum can be repaired by a primary longitudinal closure, whereas in larger defects a graft (eg, buccal) is required for urethroplasty. ${ }^{3}$

Contributors SP conceived the case report. SP and AA were major contributors towards the writing of the manuscript. AG, SP and DS treated the patient and also interpreted the patient data. SP and AA were involved in the review. All authors read and approved the final manuscript.

Funding The authors have not declared a specific grant for this research from any funding agency in the public, commercial or not-for-profit sectors.

Competing interests None declared.

Patient consent Obtained.

Provenance and peer review Not commissioned; externally peer reviewed.

\section{REFERENCES}

1 Quoraishi SH, Khan F, Besarani D, et al. Congenital anterior urethral diverticulum in a male teenager: a case report and review of the literature. Case Rep Urol 2011;2011:1-2

2 Cinman NM, McAninch JW, Glass AS, et al. Acquired male urethral diverticula: presentation, diagnosis and management. J Urol 2012;188:1204-8.

3 Alphs HH, Meeks JJ, Casey JT, et al. Surgical reconstruction of the male urethral diverticulum. Urology 2010;76:471-5.

Copyright 2018 BMJ Publishing Group. All rights reserved. For permission to reuse any of this content visit

http://group.bmj.com/group/rights-licensing/permissions.

BMJ Case Report Fellows may re-use this article for personal use and teaching without any further permission.

Become a Fellow of BMJ Case Reports today and you can:

- Submit as many cases as you like

- Enjoy fast sympathetic peer review and rapid publication of accepted articles

- Access all the published articles

Re-use any of the published material for personal use and teaching without further permission

For information on Institutional Fellowships contact consortiasales@bmjgroup.com

Visit casereports.bmj.com for more articles like this and to become a Fellow 